\begin{tabular}{l}
$\begin{array}{c}\text { Yanbu Journal } \\
\text { of }\end{array}$ \\
$\begin{array}{l}\text { Engineering } \\
\text { and Science }\end{array}$ \\
\hline ISSN: $1658-5321$ \\
Vol. 1, October $2010(1431 \mathrm{H})$
\end{tabular}

\title{
A SIMPLE SPECTROPHOTOMETRIC METHOD FOR THE DETERMINATION OF MOSAPRIDE BY DIAZOTIZATION METHOD
}

\author{
Chand Pasha ${ }^{1}$ and B. Narayana ${ }^{2}$ \\ ${ }^{1}$ Department of Chemical Engineering and Technology, Yanbu Industrial College, \\ P.O. Box: 30436, Yanbu Al-Sinaiyah, Kingdom of Saudi Arabia. \\ Email: chandchand786@yahoo.co.in \\ ${ }^{2}$ Department of Post Graduate Studies and Research in Chemistry,Mangalore University, \\ Mangalagangothri - 574 199, Karnataka, India.
}

\begin{abstract}
A facile spectrophotometric method for the determination of mosapride is described. This method is based on the reaction of mosapride with nitrite in acid medium to form diazonium ion, which is coupled with acetylacetone or ethyl acetoacetate in basic medium to form azo dyes, which shows absorption maxima at 402 or $422 \mathrm{~nm}$. The method obeys Beer's law in the concentration range of 0.4-13.5 $\mu \mathrm{gml}^{-1}$ of mosapride with acetylacetone and 0.5-17.0 $\mathrm{ggml}^{-1}$ of mosapride with ethyl acetoacetate. The molar absorptivity and Sandell's sensitivity of mosapride-acetylacetone and mosapride-ethyl acetoacetate azo dyes are $1.026 \times 10^{4} 1 \mathrm{~mol}^{-1} \mathrm{~cm}^{-1}, 4.484 \mathrm{X}$ $10^{-3} \mu \mathrm{gcm}^{-2}$ and $1.097 \times 10^{4} \mathrm{~mol}^{-1} \mathrm{~cm}^{-1}, 4.193 \times 10^{-3} \mu \mathrm{gcm}^{-2}$ respectively. The dye formed is stable for $8 \mathrm{hrs}$. The optimum reaction conditions and other analytical parameters are evaluated. No interference observed from common excipients. The method has been successfully applied to the determination of mosapride in pharmaceutical samples.
\end{abstract}

KEYWORDS: spectrophotometry, diazotization, mosapride, nitrite, acetylacetone, ethyl acetoacetate.

\section{INTRODUCTION}

Gastroprokinetic agents have an important role to play in conjunction with life style modifications in the short and long term medical management of gastroesophageal reflux disease (GERD) [1]. The prevalence of GERD and dyspepsia is increasing in many Asian countries [2]. Mosapride citrate, chemically 4-amino-5-chloro-2-ethoxy- $N$-[[4[(4-fluorophenyl) methyl]-2-morpholinyl]methyl benzamide is a potent gastroprokinetic drug. It behaves as a selective 5- $\mathrm{HT}_{4-}$ receptor agonist [3] and enhances only upper gastroprokinetic motor activity $[4,5]$.

Few methods have been reported for the determination of mosapride such as spectrofluorometry [6] and liquid chromatography [7-9]. Spectrophotometric method for the determination of mosapride 
by diazo and coupling reaction is reported earlier [10-13]. The reagents reported for the spectrophotometric determination of mosapride are less selective [13], less sensitive [10] and some require stringent experimental conditions and are carcinogenic in nature [10]. In the present work a facile, selective method for the determination of mosapride in pharmaceutical samples by spectrophotometric method is described. The amino group in mosapride is diazotized with nitrite in acidic medium at room temperature and the diazonium salt thus formed is coupled with acetylacetone or ethyl acetoacetate to give water-soluble colored dye in alkaline conditions is the basis for the determination of mosapride. The method has been successfully applied to the determination of mosapride in pharmaceutical samples.

\section{EXPERIMENTAL}

A SHIMADZU Deutschland GmbH UV2550 spectrophotometer with $1 \mathrm{~cm}$ quartz cell was used for the absorbance measurements and a WTW pH 330, pH meter were used. All chemicals used were of analytical reagent grade (Merck) or chemically pure grade and double distilled water was used for the dilution of reagents and samples. A standard solution of mosapride (Gift sample from Cipla Ltd, Mumbai, India) was prepared by dissolving the required amount of the sample in absolute alcohol and diluted with distilled water. Working solution was prepared as required by dilution. Sodium nitrite solution (0.05\%), acetylacetone (2\%), ethyl acetoacetate $(2 \%)$, hydrochloric acid $(0.2 \mathrm{M})$, sodium hydroxide $(2 \mathrm{M})$, EDTA $(0.2 \mathrm{M})$ and sodium carbonate $(1 \%)$ were used.

\subsection{GENERAL PROCEDURE FOR THE DETERMINATION OF MOSAPRIDE}

An aliquot of the sample solution containing known amount of mosapride was transferred into a series of $10 \mathrm{ml}$ calibrated flasks. To this $1 \mathrm{ml}$ of $0.05 \%$ solution of sodium nitrite and $0.5 \mathrm{ml}$ of $0.2 \mathrm{M}$ hydrochloric acid were added and the solution was shaken thoroughly for 2 minutes and kept aside for completion of diazotization reaction. Then, volumes of $1 \mathrm{ml}$ of $2 \%$ acetylacetone or ethyl acetoacetate and $2 \mathrm{ml}$ of $2 \mathrm{M}$ sodium hydroxide solutions were added and the contents were diluted to $10 \mathrm{ml}$ using double distilled water and mixed well. After 5 minutes, the absorbance of the colored azo dye formed were measured at 402 or 422 $\mathrm{nm}$ against the reagent blank.

\section{RESULTS AND DISCUSSION}

The method involves the diazotization of mosapride with nitrite, followed by the coupling of acetylacetone or ethyl acetoacetate in alkaline medium. The reaction system is represented in Fig. 1.

\subsection{EFFECT OF ACID CONCENTRATION AND TEMPERATURE ON DIAZOTIZATION}

Diazotization was carried out at room temperature $\left(25 \pm 5^{\circ} \mathrm{C}\right)$. The effect of acidity on the diazotization reaction was studied in the range $0.1-0.5 \mathrm{M}$ hydrochloric acid, and constant absorbance was observed in this range. Above this range, a decrease in the absorbance was observed. The optimum acidity for the diazotization was fixed to be $0.2 \mathrm{M}$ and minimum time for the complete diazotization was found to be 2 minutes.

\subsection{EFFECT OF THE NITRITE CONCENTRATION}

The effect of the nitrite concentration on the color intensity was studied using the proposed procedure and adding $1 \mathrm{ml}$ of $0.01-0.1 \%$ solutions of the nitrite in hydrochloric acid $(0.2 \mathrm{M})$ to a series of nitrite solutions. The results showed that a $1 \mathrm{ml}$ of $0.05 \%$ of nitrite solution was sufficient for complete color development. Higher concentration did not 
enhance the absorbance further, and lower concentration did not give good results.

\subsection{EFFECT OF COUPLING AGENT}

The effect of varying the concentration of coupling agent was studied using the proposed procedure and adding $0.2-2.0 \mathrm{ml}$ of $2 \%$ acetylacetone or $0.2-2.0 \mathrm{ml}$ of $2 \%$ ethyl acetoacetate to a series of nitrite solutions. It was found that a stable color was formed by adding $1 \mathrm{ml}$ of either acetyl acetone $(2 \%)$ or ethyl acetoacetate $(2 \%)$ solution in a final volume of $10 \mathrm{ml}$.

\subsection{EFFECT OF SODIUM HYDROXIDE CONCENTRATION}

The effect of sodium hydroxide concentration on the absorbance was studied; The effects of adding different volumes of $0.5-2.0 \mathrm{ml}$ of 2 $\mathrm{M}$ sodium hydroxide solutions were examined. The investigations showed that $1.0-1.2 \mathrm{ml}$ of $\mathrm{NaOH}$ gave maximum absorbance and $1.0 \mathrm{ml}$ of $2 \mathrm{M} \mathrm{NaOH}$ solutions was chosen for the procedure. Other alkaline solutions were tried, but best results were obtained by using sodium hydroxide.

\subsection{ANALYTICAL DATA}

The adherence to Beer's law was studied by measuring the absorbance values of solutions of variable mosapride concentrations. A straight line graph was obtained by plotting absorbance against concentration of mosapride. This method obeys Beer's law in the concentration range of $0.4-13.5 \mu \mathrm{gml}^{-1}$ for mosapride with acetylacetone and 0.5$17.0 \mathrm{\mu gml}^{-1}$ for nitrite with ethyl acetoacetate couples. The molar absorptivity, sandell's sensitivity of colored system with nitriteacetylacetone and nitrite-ethyl acetoacetate couples were found to be $1.026 \times 10^{4} \mathrm{lmol}^{-1} \mathrm{~cm}^{-1}, 4.484 \times 10^{-3} \mu \mathrm{gcm}^{-2}$ and $1.097 \times 10^{4} \quad \mathrm{lmol}^{-1} \mathrm{~cm}^{-1}, 4.193 \times 10^{-3}{\mu \mathrm{gcm}^{-2}}^{-2}$ respectively. The detection limit $\left(\mathrm{D}_{\mathrm{L}}=3.3 \sigma\right.$ / S), quantitation limit $\left(\mathrm{Q}_{\mathrm{L}}=10 \sigma / \mathrm{S}\right)$ [ where $\sigma$ is the standard deviation of the reagent blank $(n=5)$ and $S$ is the slope of the calibration curve ] and correlation coefficient for the nitrite determination with nitriteacetylacetone diazocouple and nitrite-ethyl acetoacetate diazocouple were found to be $0.137 \mu \mathrm{gml}^{-1}, 0.417 \mu \mathrm{gml}^{-1}$ and 0.9996 and

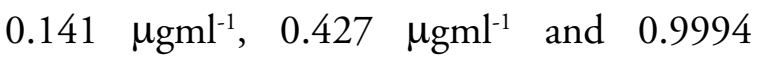
respectively.

\section{APPLICATIONS}

The proposed method was applied to the determination of mosapride in pharmaceuticals samples. The results of assay compare favorably with the reference method. (Table. $1 \& 2$ ). Statistical analysis of the results by $t$ and F-tests showed no significant difference in accuracy and precision of the proposed and reference method [14]. The other active ingradients and excipients usually present in pharmaceutical sample forms did not interfere. The reliability of the method to analyze pharmaceutical samples was checked by recovery experiments, which gave quantitative results with good reproducibility.

\section{CONCLUSIONS}

The proposed method for the determination of mosapride is simple, sensitive and reliable has a wide analytical range without the need for extraction or heating. The reagent proposed has the advantage of high sensitivity and low absorbance of reagent blank. The developed method does not involve any stringent reaction conditions and offers the advantages of high color stability ( $8 \mathrm{hrs}$ ). The proposed method has been successfully applied to the determination of mosapride in various pharmaceutical samples. 


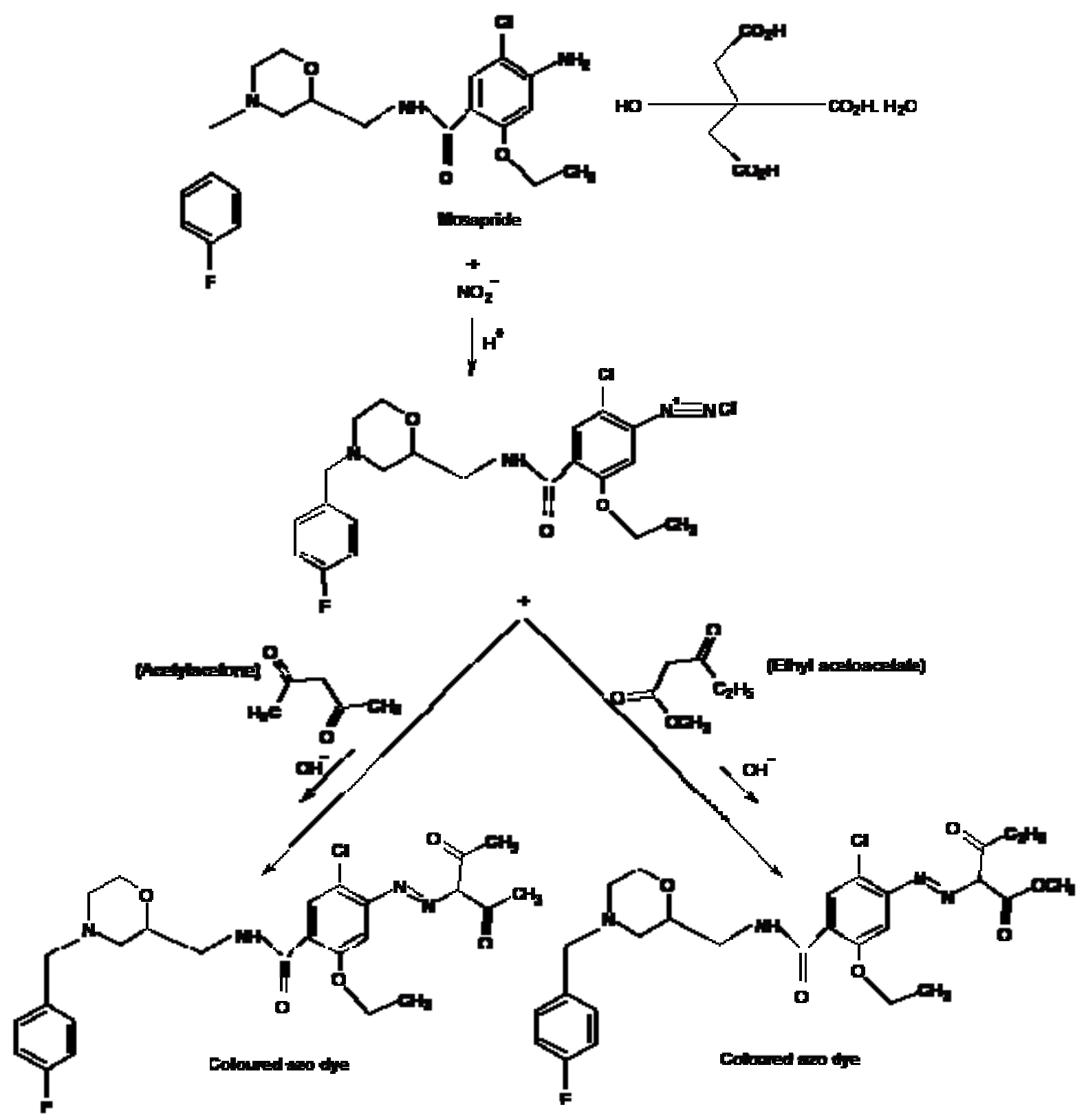

Fig.1. Presentation of the reaction scheme

TABLE. 1: DETERMINATION OF MOSAPRIDE IN DIFFERENT PHARMACEUTICAL SAMPLES USING DIAZOCOUPLE OF NITRITE WITH ACETYLACETONE

\begin{tabular}{|c|c|c|c|c|c|c|c|}
\hline \multirow[b]{2}{*}{ Samples } & \multirow{2}{*}{$\begin{array}{l}\text { SMP } \\
\text { taken } \\
\left(\mu \mathrm{g} \mathrm{ml}^{-1}\right)\end{array}$} & \multicolumn{2}{|l|}{ Proposed method } & \multicolumn{2}{|l|}{ Reference method } & \multirow[b]{2}{*}{$t-$ test $^{b}$} & \multirow[b]{2}{*}{ F-test ${ }^{c}$} \\
\hline & & $\begin{array}{l}\text { SMP found } \pm S^{a} \\
\qquad\left(\mu \mathrm{g} \mathrm{ml}^{-1}\right)\end{array}$ & $\begin{array}{c}\text { Recovery } \\
\%\end{array}$ & $\begin{array}{l}\text { SMP found } \pm S^{a} \\
\quad\left(\mu \mathrm{g} \mathrm{ml}^{-1}\right)\end{array}$ & Recovery \% & & \\
\hline
\end{tabular}


Yanbu Journal of Engineering and Science Vol. 1 (2010)

\begin{tabular}{|c|c|c|c|c|c|c|c|}
\hline $\begin{array}{l}\text { Mosid } \\
(5 \mathrm{mg} / \mathrm{tab})\end{array}$ & $\begin{array}{l}4.0 \\
8.0 \\
12.0\end{array}$ & $\begin{array}{l}3.97 \pm 0.04 \\
7.99 \pm 0.06 \\
12.00 \pm 0.04\end{array}$ & $\begin{array}{l}99.25 \\
99.87 \\
100.08\end{array}$ & $\begin{array}{l}3.95 \pm 0.07 \\
7.96 \pm 0.05 \\
11.98 \pm 0.02\end{array}$ & $\begin{array}{l}98.75 \\
99.50 \\
99.83\end{array}$ & $\begin{array}{l}0.392 \\
0.607 \\
0.707\end{array}$ & $\begin{array}{l}3.06 \\
1.44 \\
4.00\end{array}$ \\
\hline
\end{tabular}

a. Mean (SMP-Samples) \pm standard deviation $(\mathrm{n}=5)$

b. Tabulated t-value for 8 degree of freedom at $\mathrm{P}(0.95)$ is 2.306 .

c. Tabulated F-value for $(4,4)$ degree of freedom at $\mathrm{P}(0.95)$ is 6.39 .

TABLE. 2: DETERMINATION OF MOSAPRIDE IN DIFFERENT PHARMACEUTICAL SAMPLES USING DIAZOCOUPLE OF NITRITE WITH ETHYL ACETOACETATE

\begin{tabular}{|c|c|c|c|c|c|c|c|}
\hline \multirow{2}{*}{ Samples } & \multirow{2}{*}{$\begin{array}{c}\text { SMP } \\
\text { added } \\
\left(\mu \mathrm{g} \mathrm{ml}^{-1}\right)\end{array}$} & \multicolumn{2}{|l|}{ Proposed method } & \multicolumn{2}{|l|}{ Reference method } & \multirow[t]{2}{*}{$\mathrm{t}-$ test $^{\mathrm{b}}$} & \multirow[t]{2}{*}{ F-test ${ }^{\mathrm{c}}$} \\
\hline & & $\begin{array}{l}\text { SMP found } \pm S^{a} \\
\qquad\left(\mu \mathrm{g} \mathrm{ml}^{-1}\right)\end{array}$ & $\begin{array}{c}\text { Recovery } \\
\%\end{array}$ & $\begin{array}{l}\text { SMP found } \pm \text { SD }^{a} \\
\quad\left(\mu \mathrm{g} \mathrm{ml}^{-1}\right)\end{array}$ & $\begin{array}{l}\text { Recovery } \\
\%\end{array}$ & & \\
\hline $\begin{array}{l}\text { Somapride } \\
(5 \mathrm{mg} / \mathrm{tab})\end{array}$ & $\begin{array}{l}5.0 \\
10.0 \\
15.0\end{array}$ & $\begin{array}{c}4.96 \pm 0.01 \\
9.99 \pm 0.02 \\
14.95 \pm 0.06\end{array}$ & $\begin{array}{l}99.20 \\
99.90 \\
99.67\end{array}$ & $\begin{array}{l}4.94 \pm 0.02 \\
9.98 \pm 0.04 \\
14.96 \pm 0.05\end{array}$ & $\begin{array}{l}98.80 \\
99.80 \\
99.73\end{array}$ & $\begin{array}{l}1.414 \\
0.353 \\
0.202\end{array}$ & $\begin{array}{l}4.00 \\
4.00 \\
1.44\end{array}$ \\
\hline $\begin{array}{l}\text { Mozax } \\
(5 \mathrm{mg} / \mathrm{tab})\end{array}$ & $\begin{array}{l}5.0 \\
10.0 \\
15.0\end{array}$ & $\begin{array}{c}4.96 \pm 0.07 \\
9.93 \pm 0.08 \\
14.98 \pm 0.05\end{array}$ & $\begin{array}{l}99.20 \\
99.30 \\
99.86\end{array}$ & $\begin{array}{l}4.94 \pm 0.05 \\
9.95 \pm 0.06 \\
14.97 \pm 0.08\end{array}$ & $\begin{array}{l}98.80 \\
99.50 \\
99.80\end{array}$ & $\begin{array}{l}0.367 \\
0.396 \\
0.167\end{array}$ & $\begin{array}{l}1.96 \\
1.77 \\
2.56\end{array}$ \\
\hline $\begin{array}{l}\text { Mosid } \\
(5 \mathrm{mg} / \mathrm{tab})\end{array}$ & $\begin{array}{l}5.0 \\
10.0 \\
15.0\end{array}$ & $\begin{array}{c}4.99 \pm 0.04 \\
9.97 \pm 0.07 \\
14.93 \pm 0.11\end{array}$ & $\begin{array}{l}99.80 \\
99.70 \\
99.53\end{array}$ & $\begin{array}{l}4.97 \pm 0.05 \\
9.98 \pm 0.10 \\
14.95 \pm 0.13\end{array}$ & $\begin{array}{l}99.40 \\
99.80 \\
99.66\end{array}$ & $\begin{array}{l}0.493 \\
0.129 \\
0.185\end{array}$ & $\begin{array}{l}1.56 \\
2.04 \\
1.39\end{array}$ \\
\hline $\begin{array}{l}\text { Moza } \\
(5 \mathrm{mg} / \mathrm{tab})\end{array}$ & $\begin{array}{l}5.0 \\
10.0 \\
15.0\end{array}$ & $\begin{array}{l}5.04 \pm 0.06 \\
9.96 \pm 0.10 \\
14.94 \pm 0.09\end{array}$ & $\begin{array}{l}100.80 \\
99.60 \\
99.60\end{array}$ & $\begin{array}{l}5.00 \pm 0.08 \\
9.97 \pm 0.08 \\
14.91 \pm 0.06\end{array}$ & $\begin{array}{l}100.00 \\
99.70 \\
99.53\end{array}$ & $\begin{array}{l}0.632 \\
0.123 \\
0.438\end{array}$ & $\begin{array}{r}1.77 \\
1.56 \\
2.25\end{array}$ \\
\hline $\begin{array}{l}\text { Mozasef } \\
(5 \mathrm{mg} / \mathrm{tab})\end{array}$ & $\begin{array}{l}5.0 \\
10.0 \\
15.0\end{array}$ & $\begin{array}{l}4.97 \pm 0.06 \\
9.86 \pm 0.04 \\
14.84 \pm 0.08\end{array}$ & $\begin{array}{l}99.40 \\
98.60 \\
98.93\end{array}$ & $\begin{array}{l}4.96 \pm 0.05 \\
9.88 \pm 0.05 \\
14.79 \pm 0.06\end{array}$ & $\begin{array}{l}99.20 \\
98.80 \\
98.60\end{array}$ & $\begin{array}{l}0.202 \\
0.493 \\
0.790\end{array}$ & $\begin{array}{l}1.44 \\
1.56 \\
1.77\end{array}$ \\
\hline
\end{tabular}

a. Mean(SMP-Samples) \pm standard deviation $(n=5)$

b.Tabulated t-value for 8 degree of freedom at $\mathrm{P}(0.95)$ is 2.306 .

c. Tabulated F-value for $(4,4)$ degree of freedom at $\mathrm{P}(0.95)$ is 6.39 .

\section{REFERENCES}

[1] Kanaizumi, T. Nakano, H. Matsui, Y. Ishikawa, H. Shimizu, R. Park, S. and Kuriya, N., Eur. J. Clin. Pharmacol., 41, 335-337, 1991.

[2] Goh, K. L., Chang, C. S., Fock, K. M., Ke, M., Park, H. J. and Lam, S. K., J. Gastroenterol. Hepatol., 15 (3), 230-238, 2000.

[3] Carisson, L., Amos, J. G. and Anderson, B., J. Pharmacol. Exp. Therapeutics, 282, 220-227, 1997.

[4] Karasawa, T., Yoshida, N., Furukawa, K., Omoya, H. and Ito, T., Eur. J. Pharmacol., 183, 21812186, 1990.
[5] Yoshida, N., Ito, T., Furukawa, K. and Ito, Z., J. Pharm. Exp. Ther. 257, 781-787, 1991.

[6] Rajput, S. J., Sankalia, M. G. and Patel, F. T., Indian J. Pharm. Sci., 67 (5), 582-585, 2005.

[7] Krishnaiah, Y. S. R., Murthy, T. K., Sankar, D. G. and Satyanarayana, V., Anal. Sci., 18, 12691274, 2002.

[8] Krishnaiah, Y. S. R., Murthy, T. K., Sankar, D. G. and Satyanarayana, V., Pharmazie, 57 (12), 814-816, 2002.

[9] Rao, R. N., Nagaraju, D., Alvi, S. N. and Bhirud, S. B., J. Pharm. Biomed. Anal., 36 (4), 759-767, 2004. 
[10] Kuchekar, B. S., Adagale, V., Nagar, M. and Bhise, S. B., Indian J. Pharm. Sci., 65, 85, 2003.

[11] Prabhakar, B. K., Shobha, M. and Raju, S. A., J. Indian Council Chem., 20, 42, 2003.

[12] Prabhakar, B. K., Shobha, M. and Raju, S. A., Asian J Chem., 15, 1081, 2003.

[13] Raju, S. A. and Shobha, M., Asian J Chem., 15, 529-534, 2003.

[14] Revanasiddappa, H. D. and Veena, M. A., Ecl. Quim., 32 (4), 71-75, 2007. 


\title{
طريقة مبسطة للتحليل الطيفي لمادة (MOSAPRIDE) بإستخدام طريقة تكوين أصباغ الآزو
}

\author{
تشاند باشـا' و نار ايانا'

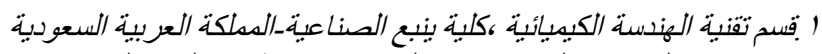

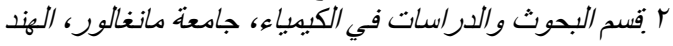

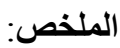

هذه الدراسة تصف طريقة مبسطة للتحليل الطيفي لمادة (mosapride). تعتمد هذه الطريقة على تفاعل مادة (acetylacetone) لتكوين أيون (diazonuim) والذ مع (mosapride) في الوسط القاعدي لتكوين أصباغ الآزو، و التي يتم إمتصاصها على طول موجي r (ethyl-acetoacetate)

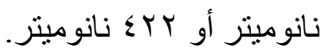

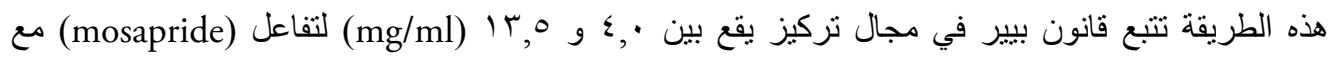

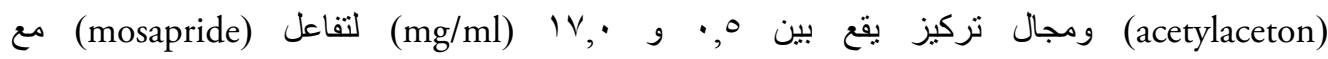
.(ethyl-acetoacetate)

لقد وجد أن قيمة الإمتصاصية المو لارية لأصباغ الآزو الناتجة من تفاعل (mosapride) مع (acetylacetone)

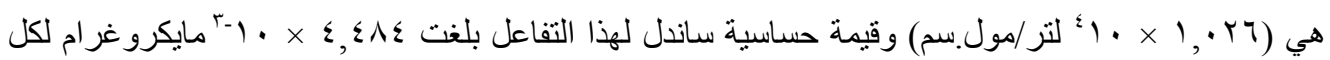

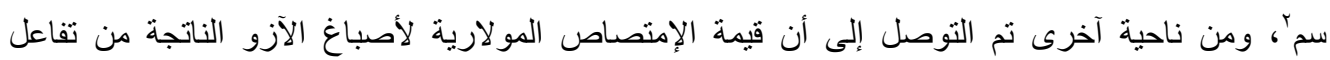
(mosapride)

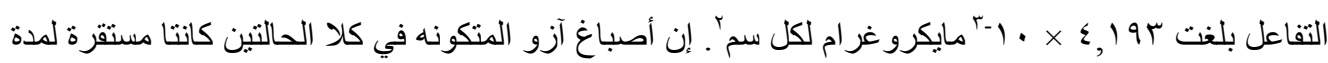

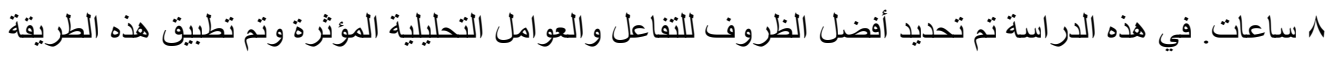
بنجاح لتحديد مادة (mosapride) في العينات الدو ائية.
\end{abstract}

